\title{
Low Carbon Strategic Analysis of Taiwan
}

\author{
Shyi-Min Lu ${ }^{1 *}$, Ching Lu ${ }^{2,3}$, Falin Chen ${ }^{1}$, Cheng-Liang Chen ${ }^{1}$, Kuo-Tung Tseng ${ }^{1}$, Pu-Ti Su$^{1}$ \\ ${ }^{1}$ Energy Research Center, Taipei, Taiwan; ${ }^{2}$ Department of Internal Medicine, Hsin-Chu Branch Hospital, National Taiwan University, \\ Taipei, Taiwan; ${ }^{3}$ Institute of Molecular Medicine, National Tsing Hua University, Hsin-Chu, Taiwan. \\ Email: accklk@yahoo.com.tw
}

Received January $10^{\text {th }}, 2013$; revised February $17^{\text {th }}, 2013$; accepted February $27^{\text {th }}$, 2013

\begin{abstract}
For four carbon-emitting sectors, the electricity, industrial, residential and commercial, and transportation sectors, this study implements the two strategies of "energy-saving and carbon-reducing measures" and "low-carbon infrastructure construction" to realize Taiwan's low-carbon vision. The electricity sector is comprised of clean coal technologies and renewable energy resources as its main power generation structure. The industrial sector adopts the Best Available Technologies (BAT) by the International Energy Agency (IEA) to save energy and reduce carbon emissions. The residential and commercial sector implements the US Energy Star benchmark for the electrical appliances to obtain the highest energy-saving effect. The transportation sector achieves a win-win outcome for energy savings and carbon reductions with the two strategies of rail mode and electrification. With detailed data analysis and strategic planning, this study concludes that Taiwan can meet the greenhouse gas (GHG) emissions goals set by both the Sustainable Energy Policy Guidelines and the UN Intergovernmental Panel on Climate Change (IPCC) for the target year of 2030.
\end{abstract}

Keywords: Low Carbon Strategy; Low Carbon Infrastructure; Taiwan

\section{Foreword: Low-Carbon Strategy}

Please refer to Figure 1. The electricity sector, upstream in Taiwan's greenhouse gas (GHG) emissions flowchart, is a major source of carbon emissions, accounting for up to $56.0 \%$ of the domestic carbon emissions. Downstream of this flowchart, carbon emissions by the four final energy consumption sectors are the industrial sector (41.5\%), commercial sector (12.4\%), transportation sector (11.8\%) and residential sector (11.8\%); their total share of carbon emissions in Taiwan is $77.5 \%$. Therefore, this study applies the low-carbon policies of Clean Sources to reduce carbon emissions from the electricity sector, which is also upstream of energy flow, and Consumption Reduction to save the energy consumed by the terminal Industrial, commerce, transport, and residential sectors. Thus, total GHG emissions can be reduced significantly to meet domestic and global targets.

The responsive means for energy saving and carbon reduction strategies are listed as follows.

- Clean sources: For the electricity sector on the supply side, low-carbon powers, such as renewable power, gas-fired power, high-efficiency coal-fired power, and nuclear power, are used to achieve low carbon emissions. Thereinafter, the proposed scenarios focus on the emerging power generation technologies.

- Consumption reduction: For major energy consumers, such as the industrial, transportation, residential and commercial sectors, energy-saving technologies can achieve reductions in carbon emissions.

- The industrial sector: This sector is comprised of six energy-intensive industries: petrochemicals; semiconductors; iron and steel; cement; paper and pulp; and textiles. The deployment of the Best Available Techniques (BAT) in these industries is a focus.

- The transportation sector: The focus in this sector is on electrical vehicles, rail transport, high-efficiency vehicles, and bio-fuels.

- The residential and commercial sector: The focus is on high-efficiency appliance, such as Light-Emitting Diode (LED) and inverter Air Conditioning (AC).

The next section describes the carbon emissions targets respectively set by Intergovernmental Panel on Climate Change (IPCC) and Taiwan's Sustainable Energy Policy Guidelines.

\section{GHG Emissions Targets of the World and Taiwan}

Climate change caused by global warming is by far the most important issue. Formed by the excessive GHG emissions, the greenhouse effect has been recognized as the main cause of global warming. Therefore, many governments in the world regard GHG emissions abatement as a top priority in terms of their energy policy, including Taiwanese government and the UN's IPCC (Intergovern- 


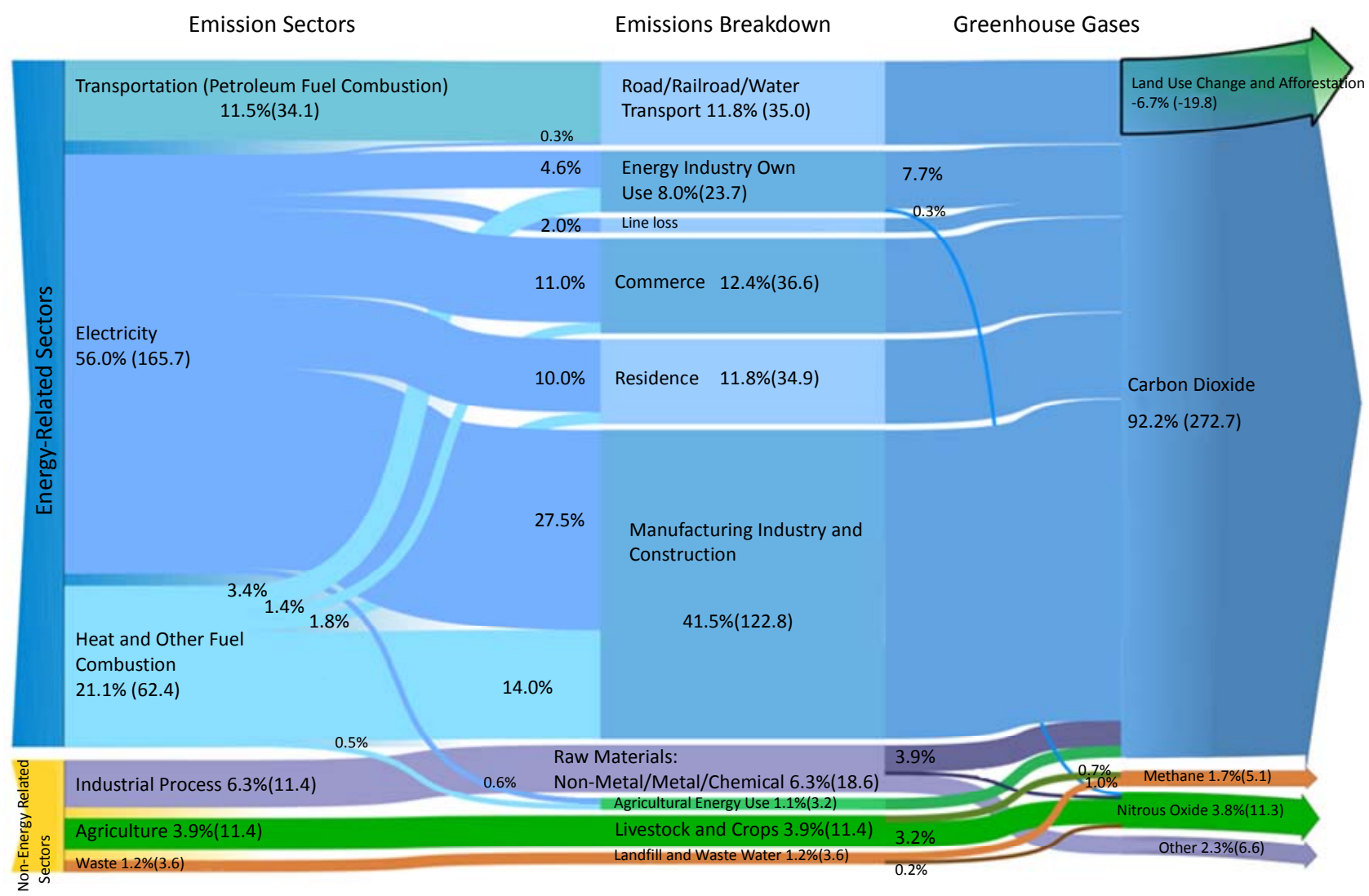

Figure 1. Taiwan GHG emissions flowchart (2008) with total emissions of 295.8 million tons of carbon dioxide equivalents. In this figure, the percentage represents the proportion of GHG emitted by each subject, while the actual emission amount is written in parenthesis, in a unit of millions of tons. Emissions accounted less than $0.1 \%$ are not included.

mental Panel on Climate Change), whereby all kinds of GHG emissions standards have been formulated.

\subsection{Carbon Emissions Status and IPCC Emissions Abatement Plan B1}

The results of a study concerning the years 2000-2006 indicate that the global annual carbon emissions due to human activities were 9.1 billion tons (equivalent to 33.4 billion tons of carbon dioxide), of which emissions from the combustion of fossil fuels were responsible for 7.6 billion tons; the remaining 1.5 billion tons were emitted as a result of changes in land-use. During the same period, for the carbon emitted into the atmosphere, 2.8 billion tons was absorbed annually by vegetation and soil; 2.2 billion tons entered the ocean; and the other 4.1 billion tons remained in the atmosphere. Accordingly, in recent years, around $45 \%$ of carbon dioxide emissions caused by human activities could not be absorbed by the oceans, soil or vegetation, and this proportion is still increasing. The greenhouse effect has been mostly responsible for a marked worsening of global weather [1].

Within the 1000 years before the year 1750, when the industrial revolution began, the concentration of carbon dioxide in the atmosphere had remained steady at 280 ppm. However, the concentration of carbon dioxide slowly increased after 1750, rising to $381 \mathrm{ppm}$ in 2006; the rate of increase between 2000 and 2006 was 1.93 ppm/yr [1]. The concentration in 2006 was not only the highest in 650,000 years [2], but also may be the highest in the past 20 million years [3]. According to the latest observations made by the US Atmospheric and Oceanic Administration, the concentration of carbon dioxide in the atmosphere reached $388 \mathrm{ppm}$ in 2010.

In 2010, the total emissions of GHGs globally reached about 47 billion tons of carbon dioxide equivalents $\left(\mathrm{CO}_{2} \mathrm{e}\right)$. Based on various possible scenarios of economic development and population growth globally over the next few decades, IPCC has generated various estimates of carbon emissions. One of the most optimistic emission scenarios (B1) for 2030 involves global total emissions of 54 billion tons of carbon dioxide equivalents $\left(\mathrm{CO}_{2} \mathrm{e}\right)$, falling to 23 billion tons in 2100 [4].

When this B1 emission scenario is simulated using 19 meteorological models, the Earth's surface temperature in the year 2100 is found to rise by $1.4-2.9$ degrees Celsius from that in 1980 to 2000 [5]. The World Climate Conference that was held in Copenhagen at the end of 
2009 designated " $2{ }^{\circ} \mathrm{C}$ ” as the target cap on global warming, with a view to mitigating the impact of global warming on human survival. The B1 scenario requires 40 billion tons of global carbon emissions in 2030 [5]. Since the global population is estimated to be 8 billion people in 2030 [6], the global carbon dioxide emissions must be limited to 5 tons/person. The B1 scenario will maintain a carbon dioxide concentration of 550 ppm in the atmosphere.

\subsection{GHG Emissions Targets of the World and Taiwan}

In 2010, carbon dioxide emissions in Taiwan were 11 tons per capita [7]. To meet the IPCC's 2030 target of 5 tons per capita, Taiwan must reduce its emissions by $54.5 \%$ from 2010 to 2030.

In 2008, Taiwan's government released the Sustainable Energy Policy Guidelines. These guidelines asserted that a sustainable energy policy must be based on the efficient use of limited resources, the development of environmentally friendly clean energy, and ensure a stable energy supply. For the development of clean energies, total carbon dioxide emissions between 2016 and 2020 should return to their level in 2008, while those in 2025 should return to their level in 2000, and those in 2050 should be reduced to $50 \%$ of those in 2000 .

According to this standard, Taiwan's carbon dioxide emissions should be reduced to 8.3 tons per capita in 2030 - the IPCC's target year. This reduction is equivalent to a reduction rate of $24.5 \%$ for the period 2010 2030. However, this emissions standard is much looser than that of the B1 scenario proposed by the IPCC for 2030.

\section{Low-Carbon Power Infrastructure}

In the following subsections, if Carbon Capture and Storage (CCS) technologies were successfully applied to fossil-fueled power plants before 2030, through scenarios analyses, we found that the option of the CCS technologies could sufficiently meet both power supply demands and GHG emissions standards, under the circumstances of no nuclear power and small amount of renewables.

\subsection{Emissions Target for Taiwan's Power Sector in Response to Global Warming}

According to a forecast by Bureau of Energy (BOE), the power supply needed in 2029 would be 276.26 billion kilowatt-hours [8]. Suppose that the average annual growth rate remains unchanged, the power needed for 2030 will be 386.79 billion kilowatt-hours or $45.5 \mathrm{kWh} /$ personday.

This study defines "power supply” as "power used by the power plant” subtracted from "power generated”. In 2011 BOE data [9], the percentage of power generated that was used by power plants was $8.09 \%$. Thus, the minimal "total power generation" target for 2030 Taiwan would be $49.5 \mathrm{kWh}$ /person-day.

According to the BOE [7], the share of GHG emissions by the power sector in 2010 was $59.4 \%$ of that of all sectors. Assuming this percentage remains unchanged until 2030, in the BAU (Business As Usual) scenario, the remaining $40.6 \%$ would come from miscellaneous emissions items.

As mentioned, 5.0 ton- $\mathrm{CO}_{2} \mathrm{e} /$ person is the emissions target for Taiwan for 2030. Relative to the 11 ton- $-\mathrm{CO}_{2} \mathrm{e} /$ person in 2010, the total reduction in carbon dioxide emissions would be $54.5 \%$. We reasonably assumed that the "miscellaneous sector" would also reduce its carbon emissions by $54.5 \%$, such that the power sector would at least reduce its annual carbon dioxide emissions to 2.03 tons $=5.0-(11.0 \times 40.6 \% \times(1-54.5 \%))$, and that is the power emissions target set by this study for scenarios in 2030.

\subsection{Taiwan's Future Development Programs: The BAU Cases}

According to the average annual growth rate of $2.8 \%$ forecasted in the "Long-Term Load Forecast and Development of Power Supply Summary Report” [8], total installed capacity of traditional power plants in 2030 would be $65.31 \mathrm{GW}$. Furthermore, according to the BOE [8], Tainwan's target for renewable energy in 2030 is 10.77 GW. Obviously, the Taiwanese government is moving its power infrastructure toward a low-carbon society.

\subsection{Characteristics of Various Power Generation Technologies}

This study analyzed the characteristics of many power generation technologies by comparing their performance parameters, such as emissions, availability, generation cost, and net peak output parameter, to achieve the optimal design of a low-carbon power structure for Taiwan (Table 1).

\subsection{Least-Cost Scenarios for Low-Carbon Power Generation}

This study applied least-cost analyses to Taiwan's lowcarbon power infrastructure. Table 2 shows the details of scenarios. For each scenario, 12 different powers exist: coal fired; gas fired; oil fired; nuclear; hydro; wind; solar photovoltaics (PV); biomass; energy from waste; geothermal; fuel cell; and ocean energy. The CCS technologies are only implemented in coal-fired and gas-fired power plants. Although nuclear power is a low-carbon energy, the 2030 scenario was designed without nuclear 
Table 1. The emissions, availability, generation cost, and net peak output parameter of all kinds of power plants.

\begin{tabular}{|c|c|c|c|c|c|}
\hline & A & B & $\mathrm{C}$ & $\mathrm{D}$ & $B \times D \div A \div C$ \\
\hline туре of power plant & $\begin{array}{c}\text { Emissions } \\
\left(\mathrm{kg}-\mathrm{CO}_{2} \mathrm{e} / \mathrm{kWh}\right)\end{array}$ & Availability & $\begin{array}{l}\text { Generation cost } \\
(\mathrm{NTD} / \mathrm{kWh})^{*}\end{array}$ & $\begin{array}{c}\text { Net peak output parameter } \\
{[8]}\end{array}$ & Scenario constitution priority \\
\hline Coal-fired & $0.839[10]$ & $0.78[8]$ & $1.28[11,12]$ & 0.94 & 0.68 \\
\hline Coal-fired + CCS & $0.125[13]$ & $0.66[10,11]$ & $1.8[12]$ & 0.80 & 2.35 \\
\hline Gas-fired & $0.389[10]$ & $0.65[10]$ & $1.57[11,12]$ & 0.98 & 1.04 \\
\hline Gas-fired + CCS & $0.25[13]$ & $0.55[10,11]$ & $2.2[12]$ & 0.83 & 0.83 \\
\hline Oil-fired & $0.778[14]$ & $0.26[10]$ & $1.42[12]$ & 0.90 & 0.21 \\
\hline Nuclear & $0.066[14]$ & $0.92[10]$ & $1.7[12]$ & 0.94 & 7.71 \\
\hline Hydropower & $0.0115[13]$ & $0.37[15]$ & $2.539[16]$ & 0.70 & 8.87 \\
\hline Wind power & $0.010[14]$ & $0.3[15]$ & $1.75[12]$ & 0.06 & 1.03 \\
\hline Solar PV & $0.032[13]$ & $0.15[17]$ & $4.3[12]$ & 0.20 & 0.22 \\
\hline Biomass power & $0.018[14]$ & $0.57[13]$ & $2.3[12]$ & 0.50 & 6.88 \\
\hline Waste energy & $0.341[18]$ & $0.52[13]$ & $2.0[12]$ & 0.80 & 0.61 \\
\hline Geothermal & $0.038[14]$ & 0.9 [19] & $1.8[20]$ & 0.50 & 6.58 \\
\hline Fuel cell & $0.664[14]$ & 0.9 [13] & 2.7 [19] & 0.85 & 0.43 \\
\hline Marine energy & $0.0375[13]$ & 0.3 [13] & $3.981[16]$ & 0.85 & 1.71 \\
\hline
\end{tabular}

Note: 1 USD $=30$ NTD; 1 GBP $=48$ NTD.

power. Therefore, the two design principles-CCS and no nuclear power-were used to satisfy the total power generation threshold, emissions standard, and minimum reserve capacity ratio to obtain the most cost-effective power structure.

\subsubsection{The Selection Method for the Power Structure in Each Scenario}

According to the positive and negative effects of each parameter, this study weighted all types of power (Table 1). Of the four capacity selection parameters, the emissions factor and cost of power generation were regarded as negative parameters, namely, as their value decreases, the performance of a scenario increases. As the values of availability and net peak output parameters, which are positive impact parameters, increase, the ability to achieve the minimum standards for generating capacity and reserve capacity ratio increases.

\subsubsection{BAU Scenario Analysis}

After calculations on an Excel spreadsheet, the 2030 BAU total generating capacity of $51.07 \mathrm{kWh} /$ person-day meets the target power generation of $49.50 \mathrm{kWh} /$ personday; however, annual emissions per capita are 10.84 ton$\mathrm{CO}_{2}, 1.67$ times the annual emissions per capita in the power sector in 2010 of 6.49 ton- $\mathrm{CO}_{2}, 1.88$ times the car- bon emissions target set by the Sustainable Energy Policy Guidelines for 2025 of 5.76 ton- $\mathrm{CO}_{2}$, and 1.88 times the IPCC carbon emissions standard of 2.97 ton- $\mathrm{CO}_{2}$ (Table 2). In the 2030 BAU scenario, since the development of renewable energy is only $3.12 \%$ of total potential, the cost of power generation does not generally increase when compared with that in 2010. Although the reserve capacity ratio is $9.43 \%$, this should not be a problem, as it can be overcome by moderately increasing fossil-fuel power generation. The problem is simply that carbon emissions are too high.

\subsubsection{Comparison and Analysis of the Scenarios of CCS and No Nuclear Energy}

In the planned scenario, no nuclear power plant will be operational in 2030. The installed capacities of CCS for fossil-fuel power plants are maintained at BAU levels (i.e., approximately 1.1 times BAU levels), while those of renewable energies are about 2.6 times BAU levels. When generation cost is $36.92 \%$ over that in 2010 , this scenario meets the required power generation by Taiwan and the emissions standard of IPCC.

From analyses of these four scenarios, this study concludes that with slightly high emissions, the low cost and high stability allow CCS to replace nuclear power as a major low-carbon power generation technology. 
Table 2. Scenarios analyses of low-carbon power infrastructure of Taiwan.

\begin{tabular}{|c|c|c|c|c|c|}
\hline & Scenario & 2010 & 2030 BAU & $\begin{array}{l}\text { Full development of } \\
\text { total RE reserves }\end{array}$ & $\begin{array}{l}2030 \text { with CCS, no nuclear scenario: } \\
\text { RE (2.6 times), CCS + fossil fueled } \\
\text { (1.1 times) }\end{array}$ \\
\hline \multirow{14}{*}{ 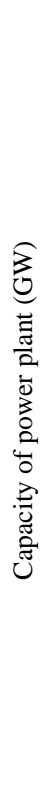 } & Coal-fired & 31.30 & 18.01 & - & 0.00 \\
\hline & Coal-fired + CCS & - & - & - & 42.50 \\
\hline & Gas-fired & 27.30 & 15.72 & - & 0.00 \\
\hline & Gas-fired + CCS & - & - & - & 24.00 \\
\hline & Oil-fired & 2.43 & 4.19 & - & 0.00 \\
\hline & Nuclear & 2.70 & 5.14 & - & 0.00 \\
\hline & Hydropower & 2.67 & 1.98 & 43.49 & 16.30 \\
\hline & Wind power & 3.11 & 0.48 & 95.51 & 4.00 \\
\hline & Solar PV & 2.66 & 0.02 & 155.06 & 3.00 \\
\hline & Biomass power & 0.34 & 0.18 & 3.06 & 1.50 \\
\hline & Waste energy & 1.25 & 0.65 & 0.00 & 1.25 \\
\hline & Geothermal & 0.20 & 0.00 & 0.71 & 0.75 \\
\hline & Fuel cell & 0.27 & 0.00 & 0.00 & 0.20 \\
\hline & Marine energy & 0.27 & 0.00 & 14.60 & 1.00 \\
\hline \multirow{7}{*}{ 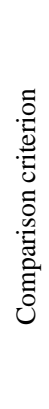 } & Total generation (kWh/person-day) & 51.07 & 32.77 & 78.02 & 53.65 \\
\hline & $\begin{array}{l}\text { Minimum power generation forecasted by } \\
\text { Taipower (kWh/person-day) }\end{array}$ & \multicolumn{4}{|c|}{49.50} \\
\hline & GHG emissions (ton- $\mathrm{CO}_{2} \mathrm{e} /$ person-yr) & 10.84 & 6.50 & 1.47 & 2.73 \\
\hline & IPCC emissions goal (ton- $\mathrm{CO}_{2} \mathrm{e} /$ person-yr) & \multicolumn{4}{|c|}{2.73} \\
\hline & Percentage of total RE reserves & 3.12 & 1.10 & 100.00 & 10.69 \\
\hline & Increase percentage of generation costs (\%) & 0.60 & 0.00 & 92.35 & 36.92 \\
\hline & Reserve capacity ratio (\%) & 9.43 & 19.35 & 36.71 & 16.01 \\
\hline
\end{tabular}

\section{The Industrial Sector's Energy Conservation}

According to statistics from the BOE in 2010, Taiwan's industrial sector consumed about 64.7 million kiloliters of oil equivalent, accounting for $53.81 \%$ of the total final energy consumption (about 120.31 million kiloliters of oil equivalent) [9].

\subsection{Introduction to Industrial Manufacturing Processes and the Latest Energy-Saving Technologies}

The BAT is from the European Union's IPPC (Integrated Pollution Prevention and Control) directive, and means prevention or reduction of overall environmental impact by best processes, equipment, or operational methods. Therefore, BAT is broadly defined as the best energysaving and emissions-reducing technologies that are economically viable. Best Practice Technology (BPT) is from the IEA's (International Energy Agency) 2006 world energy report. The report determined the energy-saving potential of a nation if it applied BPT to its chemical processes.

The common BAT used in the industrial sector includes cogeneration (i.e., combined heat and power (CHP), efficient motor and steam systems, waste heat recovery, and utilization of waste. In terms of fuel and raw material substitution, extensive use of biomass energy is an important measure. If one intends to achieve emissions targets, CCS is the most critical technology.

Two energies are generally used in industrial processes, namely, heat and electricity. For manufacturing facilities, the former is mainly used by boilers, while the latter is mostly used by motors. The common energy-saving measures for boilers are highly efficient combustion techniques and excellent performance of heat transferring mechanisms, while those for motors are inverters and power control techniques. 


\subsection{Maximal Energy-Saving Potential for Taiwan's Industrial Sector under BAT}

Table 3 shows the energy uses and GHG emissions of the six largest industries of Taiwan respectively in 2010 and 2030. By comparing quantities of energy use per output value, i.e., energy intensity (loe/NT\$1000), one can determine which industry belongs to which energy-intensive industry in Taiwan. Of six industries, the energy intensity of the cement industry (50.48 loe/NT\$1000) is highest, followed by that of the petrochemical industry (14.85 loe/NT\$1000), both of which are significantly higher than the average of 8.46 loe/NT\$1000. The Industries with very low energy use per output value are the semiconductor (1.00 loe/NT\$1000), the steel and iron industry (4.25 loe/NT\$1000) and the textiles industry (5.15 loe/NT\$1000).

Table 3 lists the energy uses and GHG emissions from the six most energy-intensive industries [7,9]. The energy use (103 kloe) and GHG emissions $\left(\mathrm{Mt}-\mathrm{CO}_{2} \mathrm{e}\right)$ for each industry are divided by output value (100 million NT\$). Thus, one can obtain all industrial energy intensities (loe/ NT\$1000) and emissions intensities ( $\left.\mathrm{kg}-\mathrm{CO}_{2} \mathrm{e} / \mathrm{NT} \$ 1000\right)$.

The industries with emissions intensities far exceeding the average (7.71 $\left.\mathrm{kg}-\mathrm{CO}_{2} \mathrm{e} / \mathrm{NT} \$ 1000\right)$ are the cement $\left(143.65 \mathrm{~kg}-\mathrm{CO}_{2} \mathrm{e} / \mathrm{NT} \$ 1,000\right)$ and paper and pulp Industries (14.89 kg- $\left.\mathrm{CO}_{2} \mathrm{e} / \mathrm{NT} \$ 1000\right)$, while the industry with the lowest emissions intensity is the semiconductor industry (2.54 kg- $\left.\mathrm{CO}_{2} \mathrm{e} / \mathrm{NT} \$ 1000\right)$. Obviously, an industry with a high emissions intensity also has a high energy intensity, and vice versa.

Table 3 shows the maximal energy-saving potential of the six major industries in Taiwan if BAT or BPT were introduced. The semiconductor industry with a high percentage of electrical energy usage has the highest energy saving potential at $27.0 \%$, followed by $21.3 \%$ for the cement industry, $20.3 \%$ for the paper and pulp industry, $20.0 \%$ for the textiles industry, and $13.2 \%$ and $12.2 \%$, respectively, for the petrochemical and iron and steel industries.

According to the IEA's estimation [21], the average energy-saving potential of the global industrial sector under the BAT scenario is roughly $18 \%$. According to this study, that for Taiwan is about $14.5 \%$. An industry with a high energy-saving potential means that its processes are energy inefficient or its equipment is dated, and large-scale improvements and updates are needed. By contrast, an industry with a low energy-saving potential means that its processes are advanced. The resulting competitiveness will increase corporate earnings. In Taiwan, the successful examples are the China Steel Corporation and Formosa Plastics Corporation; both companies represent profit-leading enterprises for the iron and steel industry and petrochemical industry in Taiwan, respec- tively. Additionally, the energy intensity of semiconductor products in Taiwan is as low as 1.00 loe/NT\$1000 (Table 3), which is why Taiwan's semiconductor Industry earns high profits. However, an analysis in Table 3 shows that because the energy-saving potential of the semiconductor industry is $27 \%$, a lot of room for improvement exists for energy savings in the semiconductor industry. The petrochemical industry has the largest energy savings of $4057.6 \mathrm{MLOE}$, accounting for $64.1 \%$ of total energy saving of the six largest industries and for $6.3 \%$ of the entire industrial energy use. Therefore, one can see how significant the effect of energy savings by the petrochemical industry would have on the entire industrial sector. Notably, the cement industry has the highest energy intensity at 50.48 loe/NT\$1000, and the second largest energy-saving potential at 21.3\% (Table 3). Obviously, the cement industry is a high energy-intensive and high pollution industry. Taking 2010 as the base year, maximal energy-saving potential for the six largest industries in Taiwan is $14.5 \%$, equivalent to $5.3 \%$ of the total energy use per year. By emissions coefficients and thermoelectric conversion efficiency (0.4), this study obtains the maximal reductions in GHG emission volumes for the six largest industries in Taiwan (Figure 2). Overall, a positive relation- ship exists between energy use and GHG emissions for Taiwan's industries.

\section{The Green Transport Infrastructure}

Among many planning programs, this study focuses only on the most energy-saving program, achieved by 1) maximizing the transport of Mass Rapid Transit (MRT); 2) increasing the number of runs of Taiwan's high-speed rail and the Taiwan Railway; and 3) partly electrifying buses, cars, and motorcycles. This is the best energy-saving and carbon-reducing program for manned transportation in Taiwan for the period 2010-2030.

- Expanding operations of the Taipei MRT to 3 times that of 2010.

- Expanding operations of the Taichung MRT to 2 times that of 2020. Two new lines will be completed for the Taichung MRT in 2020, the transport volume

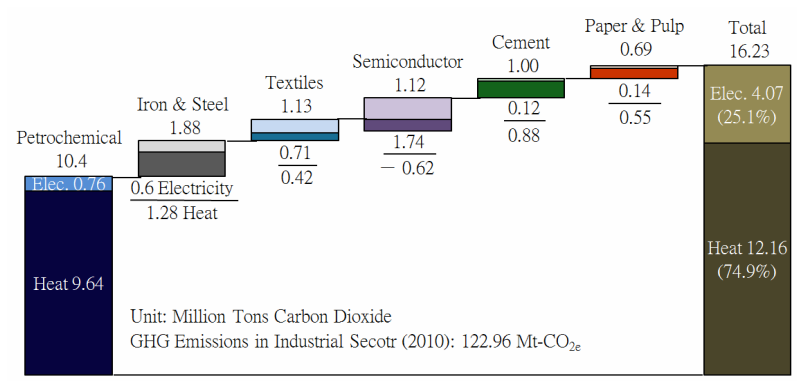

Figure 2. Emissions abatement potentials of the six largest industries in Taiwan (Base year: 2010). 
Table 3. The energy uses and GHG emissions of the six largest industries of Taiwan respectively in 2010 and 2030.

\begin{tabular}{|c|c|c|c|c|c|c|c|c|c|c|c|}
\hline Index & $\begin{array}{r}\text { Energ } \\
\text { use/Indu } \\
\text { sector s }\end{array}$ & $\begin{array}{l}\text { sy } \\
\text { strial } \\
\text { hare }\end{array}$ & $\begin{array}{c}\text { GHG } \\
\text { emissions }\end{array}$ & Output value & $\begin{array}{l}\text { Energy } \\
\text { intensity }\end{array}$ & $\begin{array}{l}\text { Emissions } \\
\text { intensity }\end{array}$ & $\begin{array}{r}\text { Energy- } \\
\text { poter }\end{array}$ & $\begin{array}{l}\text {-saving } \\
\text { ntial }\end{array}$ & $\begin{array}{l}\text { Emissions-abating } \\
\text { potential }\end{array}$ & $\begin{array}{l}\text { Main } \\
\text { product }\end{array}$ & $\begin{array}{l}\text { Main energy } \\
\text { use process }\end{array}$ \\
\hline Industry/Unit & MLOE & $\%$ & $\mathrm{Mt} \mathrm{CO} 2$ & $\begin{array}{c}100 \text { million } \\
\text { NT\$ }\end{array}$ & $\begin{array}{l}\text { loe } / 1000 \\
\text { NT\$ }\end{array}$ & $\begin{array}{c}\mathrm{kgCO}_{2} / 1000 \\
\text { NT\$ }\end{array}$ & MLOE & $\%$ & $\mathrm{Mt} \mathrm{CO}_{2}$ & - & - \\
\hline Petrochemical & 30739.4 & 47.5 & 21.9 & 20,700 & 14.85 & 10.58 & 4057.6 & 13.2 & 10.40 & Ethylene & Distillation \\
\hline Steel and iron & 6028.9 & 9.3 & 11.8 & 14,187 & 4.25 & 8.32 & 735.5 & 12.2 & 1.89 & $\begin{array}{l}\text { Crude } \\
\text { steel }\end{array}$ & $\begin{array}{l}\text { Iron oxide reduction in blast } \\
\text { furnace }\end{array}$ \\
\hline Textiles & 2203.9 & 3.4 & 3.7 & 4280 & 5.15 & 8.64 & 440.8 & 20.0 & 1.13 & $\begin{array}{l}\text { Chemical } \\
\text { fiber }\end{array}$ & $\begin{array}{l}\text { Fiber-making, spinning, } \\
\text { dyeing and finishing }\end{array}$ \\
\hline Cement & 1827.2 & 2.8 & 5.2 & 362 & 50.48 & 143.65 & 389.2 & 21.3 & 1.00 & Cement & $\begin{array}{l}\text { Clinker calcinations, } \\
\text { grinding }\end{array}$ \\
\hline Semiconductor & 1617.3 & 2.5 & 4.1 & 16,158 & 1.00 & 2.54 & 436.7 & 27.0 & 1.12 & $\begin{array}{l}\text { Integrated } \\
\text { circuit }\end{array}$ & Clean room HVAC \\
\hline Paper and pulp & 1329.7 & 2.0 & 2.5 & 1679 & 7.92 & 14.89 & 269.9 & 20.3 & 0.69 & Paper & Pulping, papermaking \\
\hline Subtotal & 43746.4 & 67.5 & 49.2 & 57,366 & $7.63^{*}$ & $8.58^{* *}$ & 6329.7 & 14.5 & 16.22 & - & - \\
\hline
\end{tabular}

Notes: $1 \mathrm{MLOE}=10.47 \mathrm{GWh}$; Thermoelectric conversion efficiency = 0.4; Electricity emissions factor $=0.612 \mathrm{~kg}-\mathrm{CO}_{2} \mathrm{e} / \mathrm{kWh}^{*}{ }^{*} 2010$ average value $=8.46$ loe/thousand NT\$. ${ }^{* *} 2010$ average value $=7.71 \mathrm{kgCO}_{2} /$ thousand NT\$.

of which is assessed based on the Kaohsiung MRT.

- Expanding the transport volume of Kaohsiung MRT to 3 times that of 2010 .

- Expanding the transport volumes of Taiwan Railway and Taiwan's high-speed rail to 1.8 times and 2 times, respectively, those of 2010. The concrete measures of which are increases in the number of runs.

- Transferring the reduced volume of small passenger cars to the high-speed rail and Taiwan Railway; transfer the reduced volume of motorcycles to the MRT, as described; and transform the remaining $80 \%$ of buses, cars, and motorcycles into electrical vehicles.

The total transportation volume of the "manned sector" and "freight sector" remains unchanged during 20102030. Under transfers of transport volume between various transport means, total transport volume in 2010 is same as that in 2030, but the distribution differs. In other words, transport volumes of vehicles that are relatively energy inefficient are transferred to vehicles that are energy efficient, such that total energy use is reduced.

According to this program, the volume from decreasing the number of motorcycles is the increase in transportation volume for the MRT. The same strategy is applied to small passenger cars and rail transports. The energy saved by small passenger cars of 3425 MLOE, almost covering total energy savings for the entire manned transportation sector. Additionally, energy savings are about $50 \%$, which is significant by taking the manned transportation sector as a whole.

The transportation volume of small passenger cars is effectively transferred to the Taiwan Railway and highspeed rail. Although the volume of rail transport is increased significantly, net energy savings are remarkable due to super low energy consumption of rail transport.
Under electrification, the rate of increase in electric vehicles, such as cars and motorcycles, will be $20 \%$ in every 5 years, making this program very effective in energy conservation because the original volume of cars and motorcycles is gigantic.

The upper half of Table $\mathbf{4}$ shows the energy intensities of manned transport. The energy used by small passenger cars is about $50 \%$ of that for the entire land transportation sector, followed by $25 \%$ for large trucks. One may deduce that the energy saved for small passenger cars and large trucks is crucial to the carbon-reducing efforts of the entire transportation sector. After adopting the program of 1) maximizing MRT use, 2) increasing the number of runs of the Taiwan Railway and high-speed rail, and 3) partly electrifying buses, cars, and motorcycles, the manned transportation sector can save 3967 MLOE of energy or $51.8 \%$.

The best energy-saving and carbon-reducing program for the freight sector in Taiwan for 2010-2030 is as follows (left lower fields in Table 5).

- Transfer $80 \%$ of freight volume for large trucks to the Taiwan Railway.

- Convert $80 \%$ of small trucks into hybrid trucks.

Under the scenario that significantly reduces the volume of large trucks and remarkably increases the freight volume of the Taiwan Railway, the energy consumed by the freight sector can be reduced by 947 MLOE by deducting the inferred 2247 MLOE in 2030 from the original 3194 MLOE in 2010 (Table 5).

The lower half of Table 5 shows the energy saving program and results for freight sector. Shifting freight carried by large trucks to the Taiwan Railway and converting small trucks to hybrid mode at a ratio of $80 \%$ in terms of transportation volume, total energy savings will 
Table 4. The energy intensities of land transportations for 2010 and 2030.

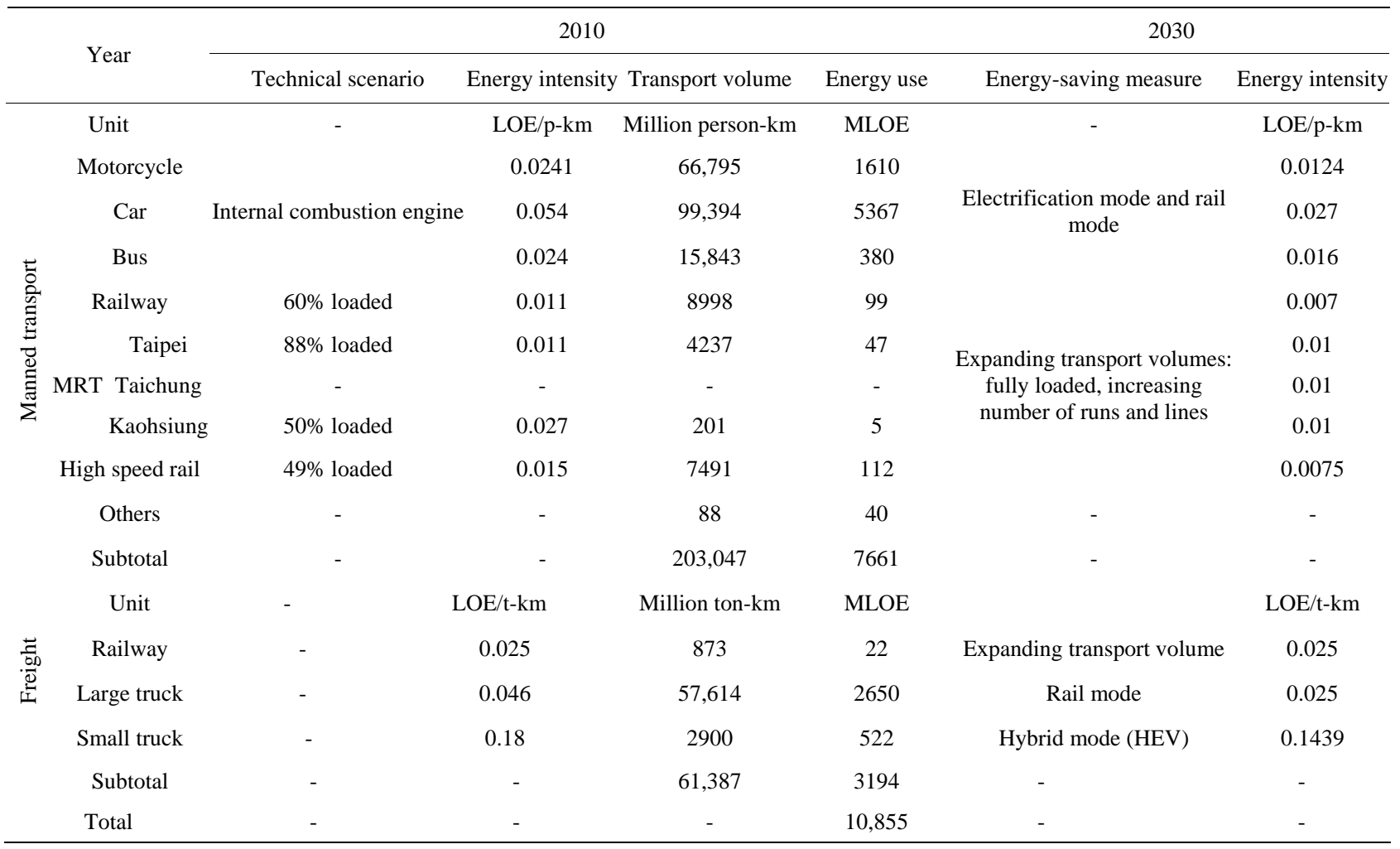

Data source: Bureau of Energy MOEA, Ministry of Transportation and Communications.

Table 5. Energy saving program and results of Taiwan's land transport sector for 2030.

\begin{tabular}{|c|c|c|c|c|c|}
\hline & \multirow{2}{*}{ Year } & \multicolumn{4}{|c|}{2030} \\
\hline & & Transport's energy-saving measures in the base year of 2010 & Transport volume & Energy use & Energy-saving volume \\
\hline & Unit & - & Million person-km & MLOE & MLOE \\
\hline \multirow{7}{*}{ 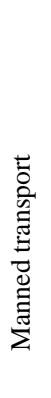 } & Motorcycle & $\begin{array}{l}\text { Partly transferring transport volume to MRT, and electrifying } \\
\text { the } 80 \% \text { remaining transport volume }\end{array}$ & 54,579 & 804 & 805 \\
\hline & Car & $\begin{array}{l}\text { Partly transferring transport volume to railway and high speed } \\
\text { rail, and electrifying the } 80 \% \text { remaining transport volume }\end{array}$ & 58,312 & 1942 & 3425 \\
\hline & Bus & Electrifying the $80 \%$ transport volume & 15,843 & 279 & 101 \\
\hline & Railway & 1.8 times the fully-loaded transport volume & 26,995 & 189 & -90 \\
\hline & Taipei & Triple the fully-loaded transport volume & 14,445 & 144 & -98 \\
\hline & MRT Taichung & Double the fully-loaded transport volume of 2020 & 1004 & 10 & -10 \\
\hline & Kaohsiung & Triple the fully-loaded transport volume & 1205 & 12 & -7 \\
\hline \multirow{9}{*}{ 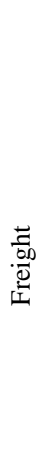 } & High speed rail & Double the fully-loaded transport volume & 30,576 & 229 & -117 \\
\hline & Others & - & 88 & 84 & -44 \\
\hline & Subtotal & - & 203,047 & 3694 & 3967 (51.8\%) \\
\hline & Unit & - & Million ton-km & MLOE & MLOE \\
\hline & Railway & $\begin{array}{c}\text { Expanding transport volume by the } 80 \% \text { transport volume of } \\
\text { large truck }\end{array}$ & 41,983 & 1050 & -1028 \\
\hline & Large truck & $80 \%$ transport volume transferred to railway & 16,503 & 759 & 1891 \\
\hline & Small truck & $80 \%$ transport volume transferred to $\mathrm{HEV}$ & 2900 & 438 & 84 \\
\hline & Subtotal & - & 61,387 & 2247 & 947 (30\%) \\
\hline & Total & - & - & 5941 & 4914 (45.3\%) \\
\hline
\end{tabular}


be 947 MLOE or 30\%. The energy savings of the largest energy consumer, large trucks, is 1891 MLOE or $70 \%$. Overall, energy-saving effectiveness is limited because the energy consumed by the Taiwan Railway increases significantly to 1006 MLOE. However, as mentioned, for the energy-saving measures of rail mode, the only measure needed is to increase the number of runs, which remains economical.

The total energy saving of both manned and freight transportation is 4914 MLOE, which is equivalent to a GHG reduction of approximately $10.56 \mathrm{Mt}-\mathrm{CO}_{2}$ or $45.3 \%$. The results account for $4.08 \%$ and $4.15 \%$ respectively of total energy use and carbon emissions.

\section{Energy Conservation of the Residential and Commercial Sector}

Taiwan's total energy consumption by the residential sector in 2010 was 12885.1 MLOE, accounting for $10.71 \%$ of the total energy consumption (BOE, 2011). Electricity consumption was $43428.6 \mathrm{GWh}$, equivalent to 10470.0 MLOE, accounting for $80.5 \%$ of that in the sector. Air conditioning accounted for approximately $28.2 \%$, followed by $25.4 \%$ for lighting, $12.9 \%$ for refrigerator, $7.2 \%$ for water dispensers, and $6.5 \%$ for television. The use of fluorescent lamp tubes accounted for $47.1 \%$ of total installed of capacity of residential lighting. The energy consumption of petroleum products and natural gas was 1317.5 MLOE and 772.7 MLOE, respectively, accounting for $10.2 \%$ and $6.0 \%$ (BOE, 2011).

In 2010, total energy consumption by the service sector was 13173.3 MOLE, accounting for $10.95 \%$ of national energy consumption. The sector's electricity consumption was 46978.3 GWh, equivalent to 11217.4 MLOE, accounting for $85.2 \%$. The energy consumption of petroleum products and natural gas was approximately 1150.2 MLOE and 460.9 MLOE, respectively, accounting for $8.7 \%$ and $3.5 \%$ in the sector (BOE, 2011). Total electricity consumption of 12 categories in the commercial office sector was 26,345 GWh. The most energy-intensive equipment in this sector was air conditioners (30.22\%), lights (17.51\%) and plugged sockets (6.87\%). The most energy-intensive buildings were office buildings (16.22\%), schools (11.05\%), and hotels (10.09\%).

The energy consumption in the residential and commercial sector accounted for $21.66 \%$ of total energy consumption in 2010. Because energy expenditure is closely related to personal habits or commercial interests, as long as the cost of an investment is recoverable, the introduction of energy-saving measures should be an incentive.

Energy consumed by the residential and commercial sector is primarily electricity, accounting for nearly $80 \%$. Air conditioners and lights are the two most energy-intensive types of equipment in this sector. Therefore, energy-saving measures in this sector should start with air conditioners and lights, such as large-scale use of highefficiency appliances. Currently, the most energy-efficient air-conditioning standard is the "US Energy Star", which has an energy-saving potential of up to $50 \%$. The most energy-efficient lighting is LED. Compared with energysaving bulbs, LED bulbs save by up to $26 \%$ of energy. Compared with the T5 florescent tube, the LED tube has a potential to reduce energy consumption by $50 \%$. The installed capabilities of LED bulbs and tubes in the residential and commercial sector are about 1:1, such that the overall energy-saving potential of lighting is about $39 \%$.

Tables 6 and 7 respectively show energy-saving potential of residential and commercial office sectors by using energy-saving equipment. Based on energy consumption in 2010, if US Energy Star equipment were introduced into the residential and commercial sectors, electricity savings will be 17.702 billion $\mathrm{kWh}$ and 10.215 billion $\mathrm{kWh}$, respectively. Therefore, total electricity-saving potential in this sector will be 27.917 billion $\mathrm{kWh}$, equivalent to a reduction in GHG emissions of $17.09 \mathrm{Mt}-\mathrm{CO}_{2}$ or $40.01 \%$.

\section{Overall Carbon Reduction}

Figure 3 shows GHG emissions abatement credited by four GHG emissions sources in Taiwan in the period from 2010 to 2030. The year 2010 is taken as the base year for calculating the total emission reduction potential. In 2010, total carbon emissions were $254.48 \mathrm{Mt}-\mathrm{CO}_{2}$, equivalent to 11 ton- $\mathrm{CO}_{2}$ per capita per year. If one applies energy-saving measures and a low-carbon infrastructure to the four sectors (i.e., electricity, residential and commercial, industrial, and transportation) GHG emissions will reduce to $106.93 \mathrm{Mt}-\mathrm{CO}_{2}$ in 2030 . Therefore, during the two decades between 2010 and 2030, a significant carbon reduction of $147.55 \mathrm{Mt}-\mathrm{CO}_{2}$ or $57.9 \%$ will be obtained. After this maximal carbon reduction, carbon emissions per capita in Taiwan will be 4.6 ton$\mathrm{CO}_{2} /$ person-yr, significantly below the target set by Sustainable Energy Policy Guidelines of $8.3 \mathrm{Mt}-\mathrm{CO}_{2} /$ personyr and just meeting the IPCC global emission target of 5 ton- $\mathrm{CO}_{2} /$ person-yr.

Next, according to the GHG emissions reduction contribution, the energy-saving measures and low-carbon infrastructure that are separately applied to the four major sectors to reduce their carbon emissions are described as follows.

1) The electricity sector: the electricity sector is a major source of carbon emissions in Taiwan, accounting for about $56.0 \%$, mainly due to the abuse of traditional thermal power plants, the installed capacity share of which is about more than $80 \%$. Therefore, the sector's low-carbon strategy is the development of clean energy, such as nuclear energy, renewable energy and CCS technology. Due to the event of nuclear disaster in Fu kushima Japan, 
Table 6. The energy-saving potential of residential sector by US Energy Star equipment.

\begin{tabular}{|c|c|c|c|c|c|c|c|c|c|}
\hline Class & $\begin{array}{l}\text { Electrical } \\
\text { appliance }\end{array}$ & $\begin{array}{c}\text { Power } \\
\text { consumption } \\
\text { (W) }\end{array}$ & $\begin{array}{c}\text { Annual energy } \\
\text { consumption } \\
(\mathrm{kWh})\end{array}$ & Penetration & $\begin{array}{c}\text { Total energy } \\
\text { consumption } \\
\left(10^{8} \mathrm{kWh}\right) \\
\end{array}$ & Share (\%) & $\begin{array}{l}\text { Model No. of electrical } \\
\text { appliance of US } \\
\text { Energy Star }\end{array}$ & $\begin{array}{c}\text { Energy-saving } \\
\text { potential (\%) }\end{array}$ & $\begin{array}{c}\text { Energy-saving } \\
\text { potential } \\
\left(10^{8} \mathrm{kWh}\right) \\
\end{array}$ \\
\hline \multirow{5}{*}{$\begin{array}{l}\text { Air } \\
\text { Conditioner } \\
\text { (AC) }\end{array}$} & $\mathrm{AC}$ & 2000 & 1200 & 2.36 & 113.78 & 25.19 & MWW-12CRN1-MI4 & 46.62 & 53.05 \\
\hline & Inverter AC & 1420 & 860 & 0.21 & 8.77 & 1.94 & MR09C1H & 52.02 & 4.56 \\
\hline & Dehumidifier & 285 & 153.9 & 0.52 & 6.43 & 1.42 & DHC-250 & 35.24 & 2.27 \\
\hline & Electric fan & 66 & 47.5 & 3.48 & 13.28 & 2.94 & AC-153X18 & 62.43 & 8.29 \\
\hline & Exhaust fan & 30 & 14.4 & 0.12 & 0.14 & 0.03 & SBF110G & 13.33 & 0.02 \\
\hline \multirow{3}{*}{ Lighting } & $\begin{array}{c}\text { Iincandescent } \\
\text { bulb }\end{array}$ & 69 & 74.5 & 4.92 & 29.45 & 6.52 & $\begin{array}{l}\text { EL/A G40 } 23 \mathrm{~W} \\
\text { (Philips) }\end{array}$ & 66.66 & 19.63 \\
\hline & $\begin{array}{c}\text { Fluorescent } \\
\text { lamp }\end{array}$ & 25 & 63 & 10.09 & 51.08 & 11.31 & $\begin{array}{l}\text { EL/Can T2 } 9 \mathrm{~W} \\
\text { (Philips) }\end{array}$ & 64.00 & 32.69 \\
\hline & $\begin{array}{c}\text { Energy saving } \\
\text { bulbs }\end{array}$ & 17 & 32 & 11.49 & 29.54 & 6.54 & LED & 47.05 & 13.90 \\
\hline \multirow[t]{2}{*}{ Power } & Elevator & 2300 & - & - & 5.36 & 1.19 & OTT & 50.02 & 2.68 \\
\hline & $\begin{array}{l}\text { Refrigerator } \\
\text { (middle) }\end{array}$ & 1100 & 661.6 & 0.41 & 21.80 & 4.83 & ARD1031F*8R/L & 22.72 & 4.95 \\
\hline \multirow{7}{*}{$\begin{array}{l}\text { Kitchen } \\
\text { appliance }\end{array}$} & $\begin{array}{l}\text { Refrigerator } \\
\text { (large) }\end{array}$ & 1500 & 700 & 0.61 & 34.31 & 7.60 & ARD1031F*11R/L & 33.33 & 11.44 \\
\hline & $\begin{array}{l}\text { Microwave } \\
\text { oven }\end{array}$ & 1200 & 72 & 0.51 & 2.95 & 0.65 & RE-0902R & 12.25 & 0.36 \\
\hline & $\begin{array}{l}\text { Electromagn } \\
\text { etic ovens }\end{array}$ & 1200 & 28.8 & 0.46 & 1.06 & 0.24 & - & 4.17 & 0.04 \\
\hline & $\begin{array}{l}\text { Water } \\
\text { Dispenser }\end{array}$ & 800 & 576 & 0.68 & 31.47 & 6.97 & MSK-9918T & 15.63 & 4.92 \\
\hline & $\begin{array}{l}\text { Electric } \\
\text { cookers }\end{array}$ & 800 & 144 & 1.02 & 11.80 & 2.61 & - & - & - \\
\hline & Electric stove & 800 & 19.2 & 0.66 & 1.02 & 0.23 & VW210EZES & 24.00 & 0.24 \\
\hline & Range hood & 350 & 126 & 0.93 & 9.42 & 2.08 & VED-8056S & 8.57 & 0.81 \\
\hline \multirow{6}{*}{$\begin{array}{l}\text { Clothes } \\
\text { appliance }\end{array}$} & Juicer & 210 & 2.5 & 0.17 & 0.03 & 0.01 & - & & - \\
\hline & Dish dryer & 200 & 36 & 0.02 & 0.06 & 0.01 & AFN50RS 27" & 19.00 & 0.01 \\
\hline & Clothes dryers & 1200 & 60 & 0.21 & 1.01 & 0.22 & - & & - \\
\hline & Irons & 800 & 48 & 0.4 & 1.54 & 0.34 & - & & - \\
\hline & $\begin{array}{l}\text { Washing } \\
\text { machine }\end{array}$ & 420 & 25.2 & 0.62 & 1.26 & 0.28 & WM2250C**(LG) & 10.00 & 0.13 \\
\hline & TV (20") & 140 & 201.6 & 0.55 & 8.91 & 1.97 & E322BV-HD & 51.38 & 4.58 \\
\hline \multirow{4}{*}{$\begin{array}{l}\text { Entertainment } \\
\text { appliance }\end{array}$} & TV (29") & 166 & 221.8 & 0.66 & 11.76 & 2.60 & E325BV-HD & 63.23 & 7.44 \\
\hline & TV (33") & 210 & 248.3 & 0.22 & 4.39 & 0.97 & E325BD-HD & 77.48 & 3.40 \\
\hline & LCD TV & 140 & 203.6 & 0.2 & 3.27 & 0.72 & - & - & - \\
\hline & Stereo & 50 & 18 & 1.37 & 1.98 & 0.44 & DX-DVD2 & 75.00 & 1.49 \\
\hline & Computer & - & 60 & 1.24 & 5.98 & 1.32 & - & - & - \\
\hline \multicolumn{2}{|c|}{ Error Correction } & - & - & - & 22.41 & 8.81 & - & - & - \\
\hline \multicolumn{2}{|c|}{ Total } & 16,782 & 3701.4 & - & 434.28 & 100.00 & - & 40.76 & 177.02 \\
\hline
\end{tabular}

anti-nuclear wave upsurges in the world, even though with low emission and cheap generation cost, Taiwan's current energy policy has to move toward the direction of less nuclear. On the other hand, renewable energy is the trend of global green energy industry, in addition to con- sidering its sustainable aspirations; the rise of the green energy industry will also promote economic development and job creation. Although their electricity prices are high and the supply is unstable currently, in scientific and technologic progressive trends, for example, the dev- 
Table 7. The energy-saving potential of commercial office sector by US Energy Star equipment.

\begin{tabular}{|c|c|c|c|c|c|c|c|c|c|c|c|c|c|c|c|c|}
\hline $\begin{array}{c}\text { User } \\
\text { equipment }\end{array}$ & $\begin{array}{l}\text { Department } \\
\text { stores }\end{array}$ & $\begin{array}{l}\text { Discount } \\
\text { store }\end{array}$ & $\begin{array}{l}\text { Convenient } \\
\text { store }\end{array}$ & t & 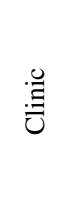 & : & 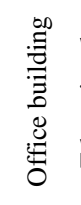 & 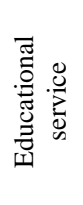 & 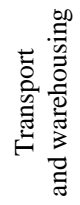 & 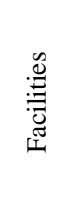 & 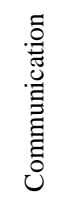 & 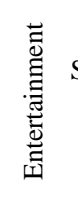 & $\begin{array}{l}\text { Subtotal energy } \\
\text { consumption } \\
\left(10^{8} \mathrm{kWh}\right)\end{array}$ & $\begin{array}{c}\text { Electric } \\
\text { consumption } \\
\text { share (\%) }\end{array}$ & $\begin{array}{c}\text { Energy- } \\
\text { saving } \\
\text { potential } \\
\text { (\%) }\end{array}$ & $\begin{array}{c}\text { Total } \\
\text { energy } \\
\text { saving } \\
\left(10^{8} \mathrm{kWh}\right)\end{array}$ \\
\hline $\begin{array}{c}\text { Air } \\
\text { Conditioning }\end{array}$ & 5.89 & 3.48 & 3.92 & 10.23 & 2.20 & 15.132 & 23.29 & 14.37 & 11.91 & 0.71 & 5.36 & 4.67 & 101.15 & $30.22 \%$ & $49 \%$ & 49.56 \\
\hline Lighting & 4.03 & 2.33 & 2.66 & 4.23 & 2.63 & 8.281 & 12.59 & 14.60 & 3.11 & 0.71 & 1.40 & 2.04 & 58.61 & $17.51 \%$ & $39 \%$ & 22.86 \\
\hline Refrigerator & 0.61 & 1.41 & 2.92 & 0.55 & 1.55 & 2.20 & 0.43 & 0.82 & 0.03 & 0.02 & 0.01 & 0.26 & 10.81 & $3.23 \%$ & $30 \%$ & 3.24 \\
\hline Socket & 0.97 & 0.44 & 2.57 & 2.44 & 0.35 & 1.69 & 6.24 & 2.07 & 3.74 & 0.13 & 1.68 & 0.68 & 23.01 & $6.87 \%$ & $28 \%$ & 6.44 \\
\hline $\begin{array}{l}\text { Air supply } \\
\text { and exhaust }\end{array}$ & 0.58 & 0.36 & - & 0.93 & 0.26 & 1.59 & 2.23 & 0.97 & 0.53 & 0.84 & 0.24 & 0.43 & 8.95 & $2.67 \%$ & $17 \%$ & 1.52 \\
\hline Sewage & 0.42 & 0.21 & - & 0.76 & 0.26 & 1.72 & 2.12 & 1.55 & 0.47 & 7.72 & 0.21 & 0.71 & 16.15 & $4.82 \%$ & $32 \%$ & 5.17 \\
\hline Elevator & 0.79 & 0.50 & - & 1.07 & - & 1.76 & 3.42 & 1.27 & 0.60 & 0.00 & 0.27 & 0.38 & 10.05 & $3.00 \%$ & $50 \%$ & 5.03 \\
\hline Others & 0.58 & 0.38 & 0.13 & 0.86 & 0.57 & 1.42 & 3.91 & 1.33 & 11.06 & 8.44 & 4.98 & 1.03 & 34.70 & $10.36 \%$ & $24 \%$ & 8.33 \\
\hline $\begin{array}{c}\text { Energy } \\
\text { consumption } \\
\text { subtotal } \\
\left(10^{8} \mathrm{kWh}\right)\end{array}$ & 13.85 & 9.12 & 12.20 & 21.04 & 7.823 & 33.785 & 54.283 & 36.98 & 31.43 & 18.60 & 14.14 & 10.21 & 263.45 & $78.70 \%$ & $39 \%$ & 102.15 \\
\hline $\begin{array}{c}\text { Electric } \\
\text { consumption } \\
\text { share (\%) }\end{array}$ & 4.14 & 2.72 & 3.64 & 6.29 & 2.341 & 10.091 & 16.22 & 11.05 & 9.39 & 5.55 & 4.22 & 3.05 & 79 & - & - & - \\
\hline
\end{tabular}

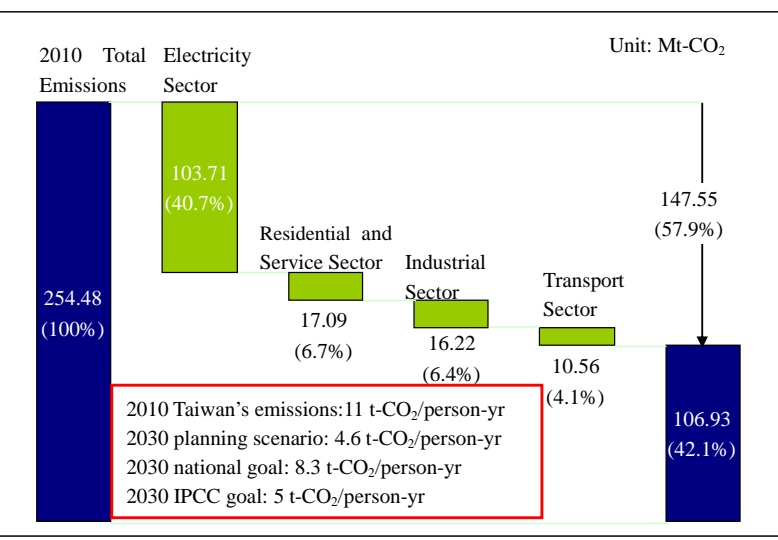

Figure 3. GHG emissions abatement credited by four GHG emissions sources in Taiwan in the period from 2010 to 2030.

elopment of energy storage technologies, renewable energy is still possible to become an electricity generation mainstream. Finally, CCS technology can be used as a low-emission power generation technology, because the biggest advantage is that global fossil energy reserves are still very abundant, such as coal and natural gas. Therefore, the specific measures and efforts to develop lowcarbon power generation infrastructure should be: with a small amount of nuclear power, all thermal power plants changed to CCS technologies, and doubling renewable energy generation capacity before 2030, then the carbon emissions in power sector will be reduced to $103.71 \mathrm{mil}-$ lion tons of carbon dioxide, with reducing scale of $40.7 \%$ in comparison with the carbon emissions in 2010.

2) Residential and commercial sector: residential and commercial sector mainly uses energy in the form of electricity. As the largest electricity consuming sector in Taiwan, the residential and commercial sector consumed 69.773 billion kWh of electricity in 2010, accounting for about $29.4 \%$ of the total electricity consumption. Air conditioning and lighting equipments are the two most energy-intensive items in the residential and commercial sector, totally consuming 41.223 billion $\mathrm{kWh}$ of electricity in 2010, accounting for $60 \%$ in the sector. Therefore, air conditioning and lighting equipments are the main object of energy saving in this sector. The specific measures are the switch to energy-efficient appliances, for example, the US Energy Star energy-saving equipments and LED. Based on the analysis of research data, the installed capacities of lighting bulbs and tubes are in the proportion of $1: 1$. If replacing $\mathrm{T} 5$ fluorescent tube with LED tube, 51\% electricity will be saved. If replacing energy saving bulbs with LED bulbs, the electricity saving will be 26\%. Please refer to Figure 2, if applying energysaving equipments labeled with "US Energy Star" and the LED lighting lamps and tubes to the residential and commercial sector, there will be a GHG emissions reduction of $17.09 \mathrm{Mt}-\mathrm{CO}_{2}$ in 2030, which accounts for 6.7\% of the total carbon emissions in 2010.

3) Industrial sector: The industrial sector is the biggest 
energy-consuming sector in all final energy consumption sectors, accounting for about 53.81\%. The main energies used are heat and electricity, the proportion of which is about 2:1. Meanwhile, the major energy-consuming equipments in the industrial sector are boilers and motors, while the specific energy-saving measures are CHP (Combined Heat and Power), waste heat recovery, high efficiency motor, re-use of waste and by-products, and so on. If IEA's BAT is all applied to Taiwan's industrial sector, there will be GHG emissions reduction of approximately 16.22 $\mathrm{Mt}-\mathrm{CO}_{2}$, equivalent to $6.4 \%$ of the 2010 total GHG emissions.

4) The transport sector: transport sector consumes energy annually of 15546.3 MLOE, accounting for $12.92 \%$ of the total energy use. The major consumed energies of the transport sector are almost entirely from petroleum products. The main energy-consuming transports on land are three kinds: small passenger cars (50\%), large trucks (25\%), and motorcycles (15\%). The specific energy-saving measures are the implementation of rail transports and the switch to electric vehicles. In the manned transports, the energy intensity of MRT is $18 \%$ that of the passenger car. Encouraging people to take MRT is the principle energy-saving guidelines for city transport. In the freight transport, the energy intensity of Taiwan Rail is about half that of large truck. Therefore, in the transport sector, if we implemented the energy-saving measures- "maximizing the transport of MRT, increasing the number of runs of Taiwan Railway and high-speed rail, and electrifying specific portions of cars and motorcycles," there will be a GHG emissions reduction of 10.56 Mt- $\mathrm{CO}_{2}$ or $4.1 \%$ compared with that of 2010 GHG emissions.

\section{The Vision of a Low-Carbon Taiwan}

In summary, by applying the two strategies of "Clean Energy and Consumption Reduction" and "Low-Carbon Infrastructure Construction” to the four sectors (i.e., electricity, industrial, residential and commercial, and transportation) to meet global carbon emissions standards will create a low-carbon Taiwan.

However, to achieve this low-carbon vision, one must take into account a number of situations, which can be briefly listed as follows.

1) "Escalating energy prices" is a "Stick Strategy". In the past, Taiwan relied on cheap energy and an exportoriented economic structure to earn profit. However, in recent years, due to the rise of the Third World economies, it can no longer rely on cheap labor and energy as competitive advantages for export trade. Industry must change its energy structure by producing high-valueadded products. Therefore, increases in energy prices will not only promote the domestic industrial structure and upgrade business objectives of high-profit products, but also engender public awareness of energy conservation and correct the habit of using products that consume large amounts of energy. Although increases in energy prices may cause a temporary inconvenience, they are essential to Taiwan's prosperity and business.

2) Electricity and transportation are the lifeblood of economy. Both stable supply and smooth operation are key factors promoting people's livelihood and economic development. One must implement carbon-reduction measures, such as the "Clean Source and Consumption Reduction" and "Low-carbon Infrastructure Construction" to achieve a low-carbon society.

3) Setting energy efficiency standards and implementing subsidies are a "radish strategy". The low-carbon vision is a hope for all the people. Under the motto that the state owns laws and the family has rules, clearly setting energy efficiency standards will make civil servants, the public, and corporations implement energy-saving and carbon-reduction measures. Additionally, subsidies can complement energy efficiency standards and further inspire a nation.

\section{Acknowledgements}

This study is a research result of the NSTPE, financially sponsored by the NSC, Taiwan.

\section{REFERENCES}

[1] G. Canadell, et al., "Contributions to Accelerating Atmospheric $\mathrm{CO}_{2}$ Growth from Economic Activity, Carbon Intensity, and Efficiency of Natural Sinks," Proceedings of the National Academy of Sciences, Vol. 104, No. 47, 2007, pp. 18866-18870. doi:10.1073/pnas.0702737104

[2] U. Siegenthaler, et al., "Stable Carbon Cycle-Climate Relationship during the Late Pleistocene,” Science, Vol. 310, No. 5752, 2005, pp. 1313-1317. doi:10.1126/science.1120130

[3] P. N. Pearson, et al., "Atmospheric Carbon Dioxide Concentrations over the Past 60 Million Years," Nature, Vol. 406, No. 6797, 2000, pp. 695-699. doi:10.1038/35021000

[4] B. Metz, et al., "Climate Change 2007: Mitigation. Contribution of Working Group III to the Fourth Assessment Report of the Intergovernmental Panel on Climate Change,” Cambridge Univeristy Press, Cambridge, 2007.

[5] M. Vermeer and S. Rahmstorf, "Global Sea Level Linked to Global Temperature," Proceedings of the National Academy of Sciences, Vol. 106, No. 51, 2009, pp. 2152721532. doi:10.1073/pnas.0907765106

[6] Department of Economic and Social Affairs, "United Nations: World Population to 2300,” 2004.

[7] Bureau of Energy, "Statistical Analysis of Taiwan Fuel Combustion Carbon Dioxide Emissions,” Bureau of Energy, Ministry of Economic Affairs, 2011.

http://www.moeaboe.gov.tw/promote/greenhouse/PrGH Main.aspx?PageId=pr_p_list

[8] Bureau of Energy, “2009-2029 Long-Term Load Forecast 
and Development of Power Supply Summary Report," Bureau of Energy, Ministry of Economic Affairs, 2010. http://www.moeaboe.gov.tw/TopicSite/Policy_price_elect ronic/Default.htm

[9] Bureau of Energy, "Energy Statistics Handbook 2010,” 2011.

http://www.moeaboe.gov.tw/promote/publications/PrPub Main.aspx?PageId=pr_publist

[10] U. Y. Du, "Road towards Low-Carbon Home-Electricity Part,” Taiwan Power Company, 2009. http://ivy1.epa.gov.tw/unfccc/chinese/_upload/p_07.pdf

[11] Sciencenet, 2011. http://bbs.sciencenet.cn/home.php?mod=space\&uid=3369 09\&do=blog\&id=488081

[12] D. Anderson, "Costs and Finance of Abating Carbon Emissions in the Energy Sector," 2006.

http://www.hm-treasury.gov.uk/d/stern_review_supportin g_technical_material_dennis_anderson_231006.pdf

[13] Parliamentary Office of Science and Technology, "Carbon Footprint of Electricity Generation,” 2006. http://www.parliament.uk/documents/post/postpn268.pdf

[14] B. K. Sovacool, "Valuing the Greenhouse Gas Emissions from Nuclear Power: A Critical Survey,” Energy Policy, Vol. 36, No. 8, 2008, pp. 2940-2953. doi:10.1016/j.enpol.2008.04.017

[15] R. Kannan, N. Strachan, S. Pye, G. Anandarajah and N. B.
Ozkan, "UK MARKAL Model: Chapter 5, Electricity and Heat Generation (and Appendix),” 2007.

www.ukerc.ac.uk

[16] S. M. Lu, "Future Energy Infrastructure of Taiwan,” Science Development, Vol. 463, 2011, pp. 66-71. (in Chinese)

[17] G. Kumbaroglu R. Madlener and M. Demirel, “A Real Options Evaluation Model for the Diffusion Prospects of New Renewable Power Generation Technologies,” Energy Economics, Vol. 30, No. 4, 2008, pp. 1882-1908. doi:10.1016/j.eneco.2006.10.009

[18] D. Hogg, “A Changing Climate for Energy from Waste? Final Report for Friends of the Earth,” Eunomia-Research \& Consulting, 2006. p. 11. http://www.foe.co.uk/resource/reports/changing_climate. pdf

[19] Toolbase, “Fuel Cells,” 2012. http://www.toolbase.org/Technology-Inventory/Electrical -Electronics/chp-fuel-cell

[20] Worldwatch, “Renewables 2007 Global Status Report," 2008. http://www.worldwatch.org/files/pdf/renewables2007.pdf

[21] IEA, "Energy Technology Transitions for Industry-Strategies for the Next Industrial Revolution,” 2009. http://www.iea.org/textbase/nppdf/free/2009/industry200 9.pdf 